Article

\title{
Fabrication of Highly Porous Polymeric Nanocomposite for the Removal of Radioactive U(VI) and Eu(III) Ions from Aqueous Solution
}

\author{
Tansir Ahamad ${ }^{1, *}$, Mu. Naushad ${ }^{1,2,3}$, Mohd Ubaidullah ${ }^{1}$ ) and Saad Alshehri ${ }^{1}$ \\ 1 Department of Chemistry, King Saud University, Riyadh 11451, Saudi Arabia; mnaushad@ksu.edu.sa (M.N.); \\ mtayyab@ksu.edu.sa (M.U.); alshehri@ksu.edu.sa (S.A.) \\ 2 Yonsei Frontier Lab, Yonsei University, Seoul 03722, Korea \\ 3 School of Life and Allied Health Sciences, Glocal University, Saharanpur 247001, India \\ * Correspondence: tahamed@ksu.edu.sa
}

Received: 4 November 2020; Accepted: 3 December 2020; Published: 9 December 2020 updates

\begin{abstract}
In the present study, a polymeric nanocomposite, $\mathrm{CoFe}_{2} \mathrm{O}_{4} @ \mathrm{DHBF}$, was fabricated using 2,4 dihydroxybenzaldehyde and formaldehyde in basic medium with $\mathrm{CoFe}_{2} \mathrm{O}_{4}$ nanoparticles. The fabricated nanocomposite was characterized using FTIR, TGA, XRD, SEM, TEM, and XPS analyses. The analytical results revealed that the magnetic nanocomposite was fabricated successfully with high surface area $370.24 \mathrm{~m}^{2} / \mathrm{g}$. The fabricated $\mathrm{CoFe}_{2} \mathrm{O}_{4} @ \mathrm{DHBF}$ was used as an efficient adsorbent for the adsorption of $\mathrm{U}(\mathrm{VI})$ and $\mathrm{Eu}(\mathrm{III})$ ions from contaminated water. $\mathrm{pH}$, initial concentration, adsorption time, and the temperature of the contaminated water solution affecting the adsorption ability of the nanocomposites were studied. The batch adsorption results exposed that the adsorption capacity for the removal of $\mathrm{U}(\mathrm{VI})$ and $\mathrm{Eu}(\mathrm{III})$ was found to be 237.5 and $225.5 \mathrm{mg} / \mathrm{g}$. The adsorption kinetics support that both the metal ions follow second order adsorption kinetics. The adsorption isotherm well fits with the Langmuir adsorption isotherm and the correlation coefficient $\left(R^{2}\right)$ values were found to be 0.9920 and 0.9913 for the adsorption of $\mathrm{U}(\mathrm{VI})$ and $\mathrm{Eu}(\mathrm{III})$, respectively. It was noticed that the fabricated nanocomposites show excellent regeneration ability and about 220.1 and $211.3 \mathrm{mg} / \mathrm{g}$ adsorption capacity remains with $\mathrm{U}(\mathrm{VI})$ and $\mathrm{Eu}(\mathrm{III})$ under optimum conditions.
\end{abstract}

Keywords: 2,4 dihydroxybenzaldehyde; polymer nanocomposite; radioactive; adsorption

\section{Introduction}

Radioactive substances can be found in the air, water, and soil, polluting the environment. However, the water source can be contaminated using radionuclides, naturally present in rock and soil or released from human activities, such as medical radiology or nuclear power plants [1-3]. The long-term exposure of the radionuclides or drinking of contaminated water can cause cancer and other disorders to the human and animals [4-6]. The World Health Organization (WHO) considers that $30 \mu \mathrm{g} \mathrm{L}^{-1}$ of Uranium is safe, but a clear no-effect concentration has not been definitively derived yet. The US Environmental Protection Agency (EPA) has adapted this value. Therefore, the development of effective approaches or systems to treat the contaminated water represents an urgent demand for researchers. Several methods, including reverse osmosis, membrane filtration, solvent extraction, electrodialysis, chemical precipitation, and adsorption, have been used for the removal of toxic ions form aqueous solution [7-9]. Nevertheless, each technology has advantages and disadvantages especially regarding efficiency and costs (Supplementary Table S1). Among these methods, adsorption is the most effective method because of its high efficiency, low cost, and environmentally friendly nature [10-13]. However, for adsorption, an efficient adsorbent plays the main role and several adsorbents such as 
polymer, graphite carbon, clay, metal oxides and nanocomposites have been used for the adsorption of toxic metal ions or organic pollutants from contaminated water [14-16]. On the other hand, nowadays, nanotechnology also plays a key role in the adsorption technology and many nanomaterials have been used for the adsorption of organic and inorganic pollutants form aqueous solution [17-20]. Even so, the poor adsorption capacity and selectivity of these adsorbents reduced their applications for adsorption of radioactive ions [21,22]. Even though the adsorption capacity and selectively of the polymers based adsorbent can be tuned with the functional groups such as carboxylic (-COOH), amines $\left(-\mathrm{NH}_{2} /-\mathrm{NH}\right)$ hydroxyl $(-\mathrm{OH})$ and azomethine $(\mathrm{C}=\mathrm{N}-)$ etc. [23-26]. Up to now several polymer nanocomposites including polymer/polymer composite, polymer/carbon composite, polymer/clay composite, polymer/ metal oxide composite etc. are the advanced materials and used as adsorbent for the adsorption of several organic and inorganic pollutants from aqueous solution [3,27-31]. However, these polymer nanocomposites challenge with respect their poor, time consuming and expensive separation methods and limits their use at large and industrial scale [32-34].Therefore, the fabrication of magnetic polymer nanocomposite with excellent adsorption efficiency and selectivity is an urgent demand of the researchers. The utilization of metal oxide magnetic nanoparticles with polymer matrices provides higher stability, process ability, excellent reusability, and some exciting enhancements caused by the nanoparticle-polymer interface [35-37]. Considering these facts, herein, we have prepared a polymer nanocomposite owing to their high adsorption capacity, low cost, magnetism, low toxicity, and reusability.

The polymeric resin was fabricated using 2,4 dihydroxybenzaldehyde and formaldehyde and its magnetic nanocomposite was prepared with $\mathrm{CoFe}_{2} \mathrm{O}_{4}$ nanoparticles. As-prepared $\mathrm{CoFe}_{2} \mathrm{O}_{4} @$ DHBF was characterized successfully and used for the removal of $\mathrm{U}(\mathrm{VI})$ and $\mathrm{Eu}(\mathrm{III})$ ions from contaminated water. The batch adsorption techniques were used, changing the $\mathrm{pH}$, initial concentration, adsorbent dose, contact time, and temperature of the solution. The adsorption kinetics, isotherm, and thermodynamics studies were carried out to find out the interaction between the adsorbate and the adsorbents. Moreover, the adsorption mechanisms were fully elucidated by FT-IR and XPS.

\section{Experimental}

\subsection{Materials}

Briefly, 2,4 dihydroxybenzaldehyde, formaldehyde, cobalt(II)chloride hexahydrate, Iron(III) chloride hexahydrate, $\mathrm{NaOH}, \mathrm{HCl}$, ammonia solution, europium(III) chloride hexahydrate were purchased form Sigma Aldrich (Steinheim, Germany). Meanwhile, uranyl acetate dihydrate was purchased form BDH chemicals (Poole, UK). All reactants used were of analytical grade. All the solutions were prepared in deionised water. $\mathrm{CoFe}_{2} \mathrm{O}_{4}$ nanoparticles were prepared according to previously reported method using cobalt(II)chloride and Iron(III) chloride in 1:2 molar ratio using ammonia solution at room temperature [38,39].

\subsection{Fabrication of the Nanocomposite}

The magnetic polymer nanocomposite was fabricated using 2,4 dihydroxybenzaldehyde, formaldehyde under basic condition [40]. In a 200-mL beaker, $2.76 \mathrm{~g}$ (0.02 mol) of 2,4 dihydroxybenzaldehyde was dissolved in $10 \mathrm{~mL}$ of distilled water and the $6 \mathrm{~mL}$ of formaldehyde was added into the solution and was stirred magnetically at room temperature and the $\mathrm{pH}$ of the solution was changed to 8 using $\mathrm{NaOH}$ solution and then heated at $60^{\circ} \mathrm{C}$ for $30 \mathrm{~min}$. After that, $2 \mathrm{~g}$ of prefabricated $\mathrm{CoFe}_{2} \mathrm{O}_{4}$ nanoparticles was added and stirred mechanically at $80^{\circ} \mathrm{C}$ for $3 \mathrm{~h}$. The resulting mixture was then re-precipitated using methanol and the magnetic nanocomposite was separated magnetically. The fabricated $\mathrm{CoFe}_{2} \mathrm{O}_{4} @$ DHBF was washed, dried, and stored for further used. 


\section{Results and Discussion}

\subsection{Characterization of the Nanocomposite}

The polymers nanocomposite with $\mathrm{CoFe}_{2} \mathrm{O}_{4}$ nanoparticles was prepared using 2,4 dihydroxybenzaldehyde and formaldehyde. The fabrication method is explained in Figure 1.

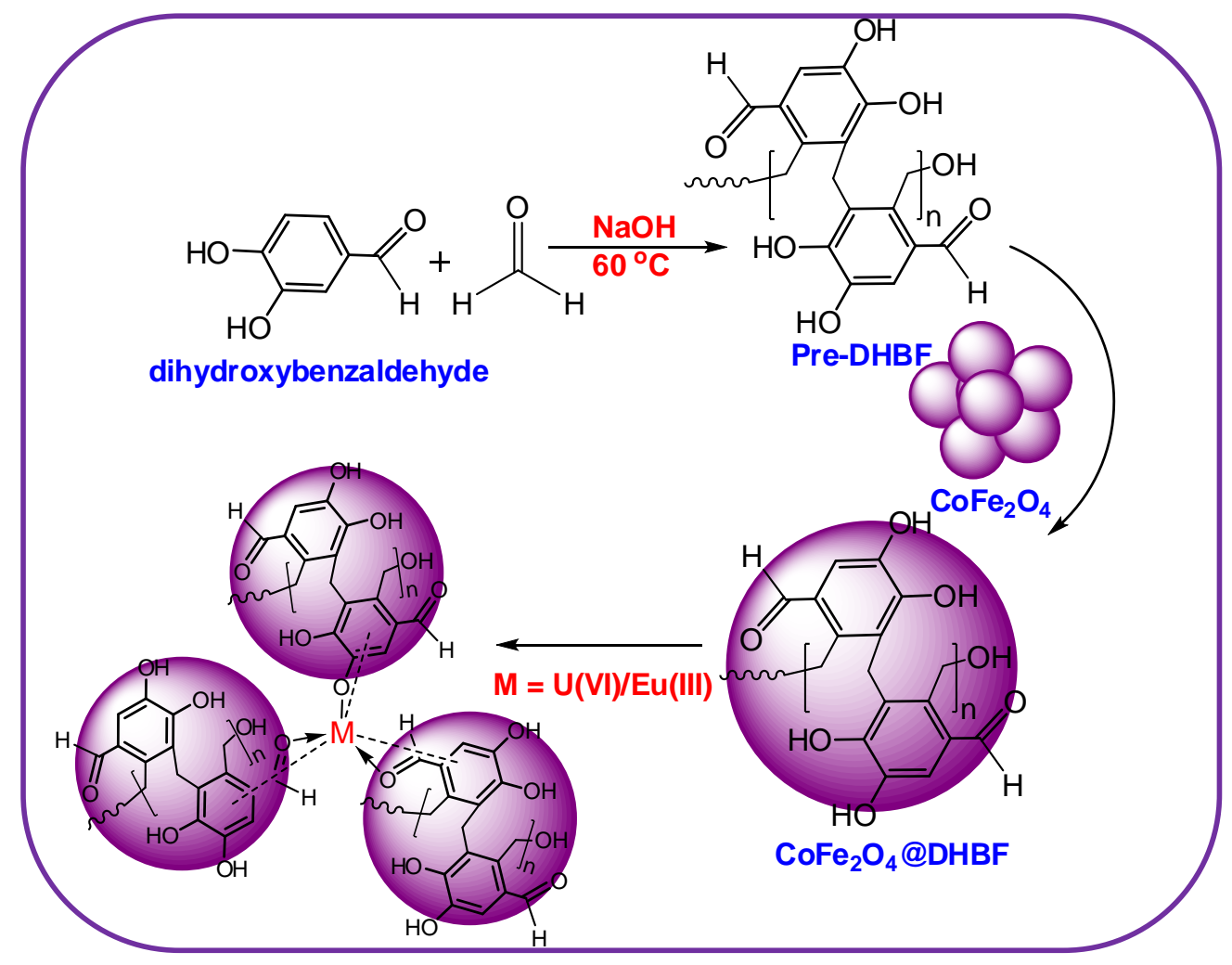

Figure 1. The synthesis routes for the synthesis of $\mathrm{CoFe}_{2} \mathrm{O}_{4} @ \mathrm{DHBF}$.

The functional group presents in the polymer and in the nanocomposite were determined using FTIR spectra as shown in Figure 2a. In the case of the dihydroxybenzaldehyde-formaldehyde based polymer resin (DHBF) several FTIR peaks were noticed at 3324-3520 cm-1 (O-H), 3044 (C-H aromatic), 2949-2845 (C-H sym and asym), 1663 (C=O), $1564(\mathrm{C}=\mathrm{C})$, and others [41,42]. Meanwhile, in the case of the magnetic polymer nanocomposite $\mathrm{CoFe}_{2} \mathrm{O}_{4} @ \mathrm{DHBF}$ the $\mathrm{C}=\mathrm{O}$ band was shifted from $1163 \mathrm{~cm}^{-1}$ to $1649 \mathrm{~cm}^{-1}$ was noticed in the presence of $\mathrm{CoFe}_{2} \mathrm{O}_{4}$ nanoparticles and support the interaction between the magnetic nanoparticles and the polymer matrix via hydrogen bonding. Another two FTIR bands were observed at 512 and $627 \mathrm{~cm}^{-1}$ and assigned to the $\mathrm{Fe}-\mathrm{O}$ and $\mathrm{Co}-\mathrm{O}$ of the spinal cobalt ferrite $[43,44]$. The TGA was used to investigate the thermal stability and the interaction between the nanoparticles and the polymer matrix in the nanocomposite $\left(\mathrm{CoFe}_{2} \mathrm{O}_{4} @ \mathrm{DHBF}\right)$. The TGA analysis of the polymer and the nanocomposites is shown in Figure $2 \mathrm{~b}$. 

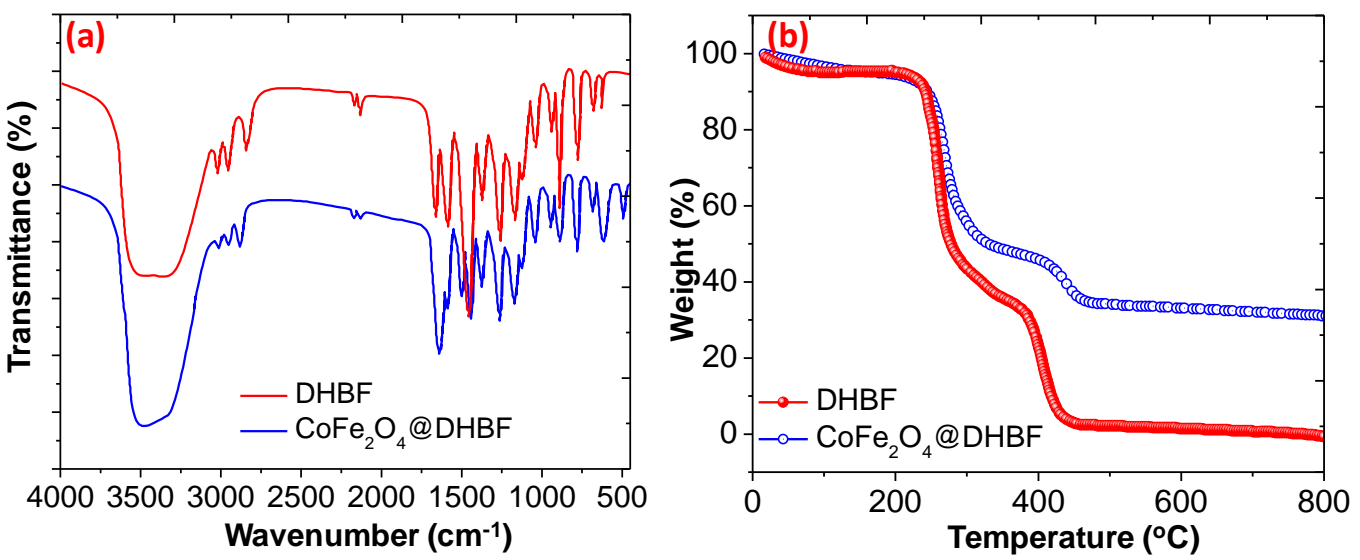

Figure 2. (a) FTIR spectra of DHBF and $\mathrm{CoFe}_{2} \mathrm{O}_{4} @ \mathrm{DHBF}$ (b) TGA/DTA curves of DHBF and $\mathrm{CoFe}_{2} \mathrm{O}_{4} @ \mathrm{DHBF}$.

Initially a slightly weight loss about to $4.21 \%$ and $5.24 \%$ was noticed for DHBF and for $\mathrm{CoFe}_{2} \mathrm{O}_{4} @ \mathrm{DHBF}$ up to $200{ }^{\circ} \mathrm{C}$ temperature due to the evaporation of adsorbed humidity and other solvents. Moreover, between 200 to $375^{\circ} \mathrm{C}$ about $62.21 \%$ and $47.48 \%$ weight loss was found and it is the main degradation stage of the organic moieties for DHBF and for $\mathrm{CoFe}_{2} \mathrm{O}_{4} @$ DHBF. The last phase is the cracking of the polymeric materials and at $500{ }^{\circ} \mathrm{C}$ about the DHBF decomposed completely while in the case of $\mathrm{CoFe}_{2} \mathrm{O}_{4} @$ DHBF about to $13.12 \%$ weight loss was notices and the residue weight was found about to 31.20 at $800{ }^{\circ} \mathrm{C}$. These outcomes revealed that the $\mathrm{CoFe}_{2} \mathrm{O}_{4} @ \mathrm{DHBF}$ shows excellent thermal stability compared to the polymeric resin, DHBF [45-47]. The XRD patterns of $\mathrm{CoFe}_{2} \mathrm{O}_{4}$, and $\mathrm{CoFe}_{2} \mathrm{O}_{4} @$ DHBF are illustrated in Figure 3a. It was noticed that the XRD peaks for pure $\mathrm{CoFe}_{2} \mathrm{O}_{4}$ nanoparticles were found at $2 \theta$ values $30.14^{\circ}(220), 35.58^{\circ}(311), 37.24^{\circ}(222), 43.34^{\circ}(400), 53.67^{\circ}(422)$, $57.08^{\circ}(511), 62.7^{\circ}(440), 71.2^{\circ}(620), 74.2^{\circ}(533), 75.2^{\circ}(622)$, and $79.2^{\circ}(444)$ and can be assigned to the $\mathrm{CoFe}_{2} \mathrm{O}_{4}$ spinel structure (JCPDS no. 22-1086) [48,49]. Moreover, in the case of the $\mathrm{CoFe}_{2} \mathrm{O}_{4} @ \mathrm{DHBF}$, the intensity of the XRD peaks are decreased without changing their position and the amorphous region peaks also appear. These results support that in the nanocomposites the spinal structure of the $\mathrm{CoFe}_{2} \mathrm{O}_{4}$ is unchanged and embedded it is pure form without any impurity. The X-ray photoelectron spectroscopy (XPS) explained the elemental composition of the $\mathrm{CoFe}_{2} \mathrm{O}_{4}$ and $\mathrm{CoFe}_{2} \mathrm{O}_{4} @$ DHBF. The XPS survey of the $\mathrm{CoFe}_{2} \mathrm{O}_{4} @$ DHBF displays the existence of the $\mathrm{C}, \mathrm{O}, \mathrm{Co}$, and Fe elements as showed in Figure $3 b$. The deconvoluted spectra of the Co $2 p$ spectra show peaks due to the Co $2 p_{3 / 2}$ and Co $2 p_{1 / 2}$ at binding energy of 780.76 and $796.65 \mathrm{eV}$ respectively [50,51]. Meanwhile, the satellites peaks, due to the presence of unpaired $3 \mathrm{~d}$ electron of the high spin $\mathrm{Co}^{2+}$ and belonging to $\mathrm{Co}_{2} 2 \mathrm{p}_{3 / 2}$ and $\mathrm{Co}_{2} 2 \mathrm{p}_{1 / 2}$, appear at a binding energy of 786.19 and $802.95 \mathrm{eV}$, as shown in Figure 3c. The XPS spectrum of Fe 2p is exposed in Figure $3 \mathrm{~d}$ and displays two peaks at a binding energy 724.04 and $711.21 \mathrm{eV}$, assigned to $\mathrm{Fe} 2 \mathrm{p}_{1 / 2}$ and $\mathrm{Fe} 2 \mathrm{p}_{3 / 2}$ respectively. These results support the presence of $\mathrm{Fe}^{3+}$ in the invers spinel $\mathrm{CoFe}_{2} \mathrm{O}_{4}$. The core-level C1s XPS spectrum is illustrated in Figure 3e and split into four peaks and appeared at binding energy about $283.94,285.8,286.80$, and $287.72 \mathrm{eV}$ and were assigned to $\mathrm{C}-\mathrm{C}, \mathrm{C}=\mathrm{C}$, $\mathrm{C}-\mathrm{O}$, and $\mathrm{C}=\mathrm{O}$ respectively [52]. The $\mathrm{O} 1 \mathrm{~s}$ spectrum was split into three peaks and the lattice oxygen appeared at a binding energy of about $529.21,530.84$, and $531.21 \mathrm{eV}, \mathrm{Fe}-\mathrm{O} / \mathrm{Co}-\mathrm{O}, \mathrm{C}-\mathrm{O} / \mathrm{C}=\mathrm{O}$, and surface $\mathrm{OH}$, respectively, as illustrated in Figure $3 \mathrm{f}[53]$. 

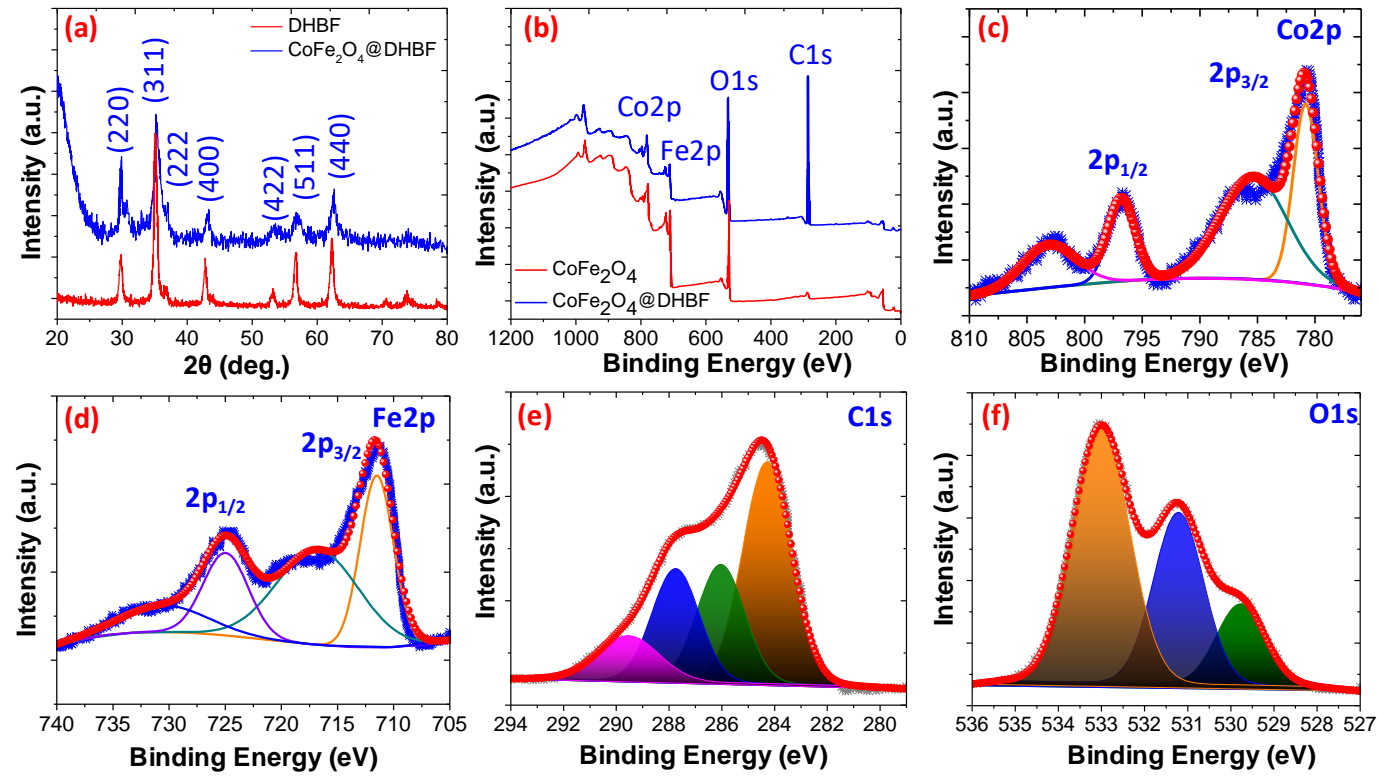

Figure 3. (a) XRD of $\mathrm{CoFe}_{2} \mathrm{O}_{4}$, and $\mathrm{CoFe}_{2} \mathrm{O}_{4} @ \mathrm{DHBF}$ (b) a wide XPS spectra for $\mathrm{CoFe}_{2} \mathrm{O}_{4}$, and $\mathrm{CoFe}_{2} \mathrm{O}_{4} @ \mathrm{DHBF}$ (c) Co2p, (d) Fe 2p (e) C 1s, (f) O1s.

The surface morphology of the nanoparticles and the nanocomposite was determined using the SEM and TEM analysis. As illustrated in Figure 4a, the SEM image of the $\mathrm{CoFe}_{2} \mathrm{O}_{4}$ shows the spherical shape with a diameter range of $14-25 \mathrm{~nm}$, the fabricated nanoparticles are aggregated due to their super magnetic nature. While in the case of the $\mathrm{CoFe}_{2} \mathrm{O}_{4} @ \mathrm{DHBF}$, the $\mathrm{CoFe}_{2} \mathrm{O}_{4}$ nanoparticles are well dispersed into the polymer matrix and no aggregation was noticed. The shape and size of the nanoparticles were unchanged in the case of the nanocomposite. The detailed morphology of the nanocomposite was monitored with a TEM image as shown in Figure 4c and showed similar results to the SEM results. The crystalline nature and the interaction with the polymer matrix were further confirmed with HRTEM analysis and illustrated in Figure 4d. The lattice fingers were noticed with d-spacing of 0.262 and $0.291 \mathrm{~nm}$, which were assigned to the (311) and (220) planes of the $\mathrm{CoFe}_{2} \mathrm{O}_{4}$ spinal structure [54-56]. The existence of pure $\mathrm{CoFe}_{2} \mathrm{O}_{4}$ in the polymer nanocomposite was further supported using selected area electron diffraction (SAED) to show the electron diffraction planes as in Figure $4 d[49,57]$. 

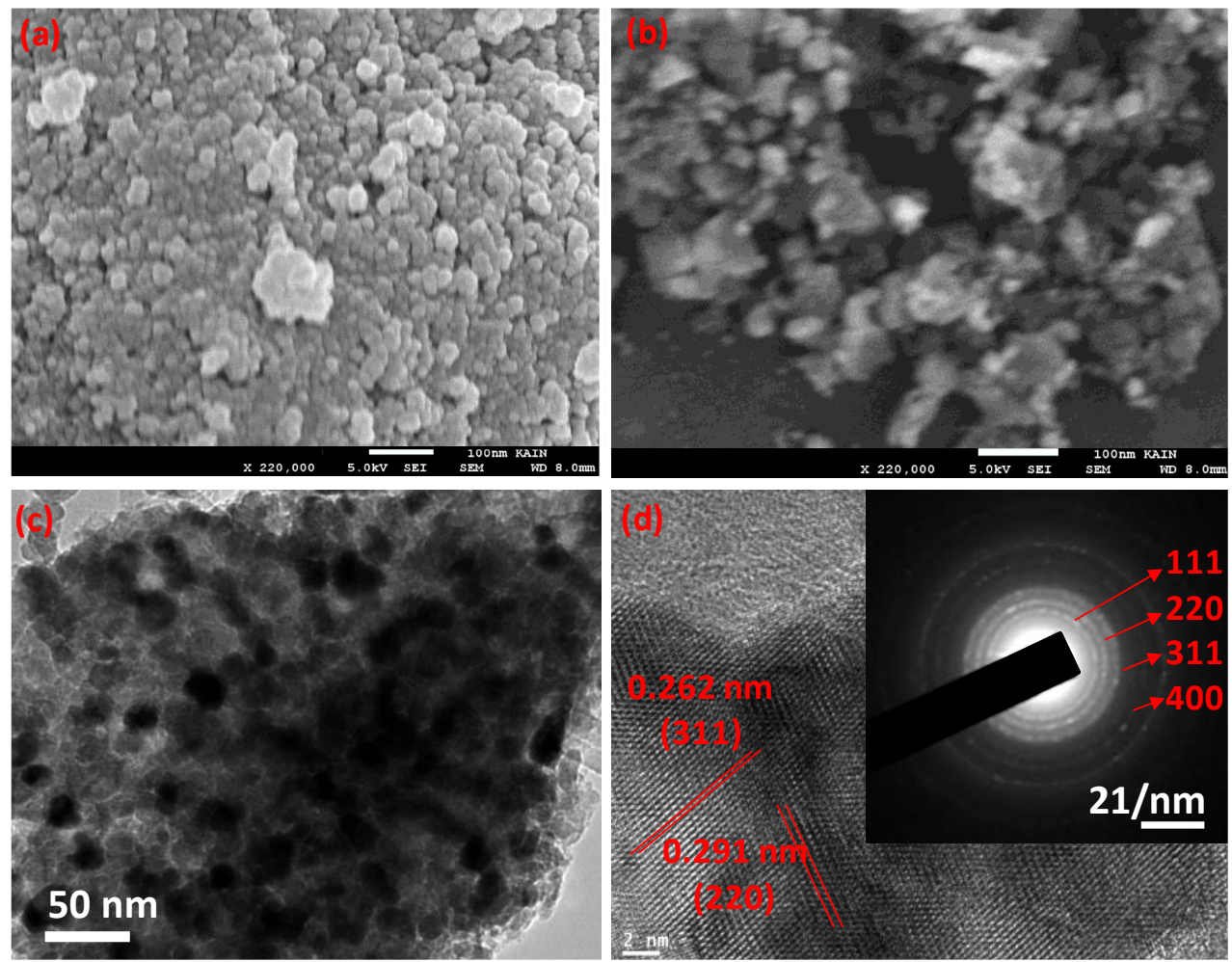

Figure 4. (a) SEM image of $\mathrm{CoFe}_{2} \mathrm{O}_{4}$ (b) SEM image of $\mathrm{CoFe}_{2} \mathrm{O}_{4} @ D H B F$ (c) TEM image of $\mathrm{CoFe}_{2} \mathrm{O}_{4} @ \mathrm{DHBF}$ (d) HRTEM image of $\mathrm{CoFe}_{2} \mathrm{O}_{4} @$ DHBF, SAED (inserted).

The $\mathrm{N}_{2}$ adsorption and desorption isotherm was used to determine the porous properties of the polymer and the nanocomposite. It was noticed that the adsorption of $\mathrm{N}_{2}$ was increased with increasing the relative pressure up to $\mathrm{P} / \mathrm{P}_{\mathrm{O}}<0.8$. As shown in Figure $5 \mathrm{a}$, the $\mathrm{N}_{2}$ adsorption-desorption shows type IV hysteresis loop and supports the mesoporous nature of the $\mathrm{CoFe}_{2} \mathrm{O}_{4} @$ DHBF. The BET results demonstrate that the surface area of the $\mathrm{CoFe}_{2} \mathrm{O}_{4}$ nanoparticles and the $\mathrm{CoFe}_{2} \mathrm{O}_{4} @$ DBF was found to be 96.54 and $370.24 \mathrm{~m}^{2} / \mathrm{g}$ respectively. As shown in inserted figure in Figure 5 a the pores size were found to be between $12-18 \mathrm{~nm}$ and $24-28 \mathrm{~nm}$ an indicate both the polymer and the $\mathrm{CoFe}_{2} \mathrm{O}_{4} @$ DHBF has mesoporous nature and suitable for the adsorption of the pollutants from aqueous solution. The magnetic behaviors of the pure $\mathrm{CoFe}_{2} \mathrm{O}_{4}$ nanoparticles and the $\mathrm{CoFe}_{2} \mathrm{O}_{4} @ \mathrm{DHBF}$ were determined using VSM (vibrating-sample magnetometer) analysis and the results were illustrated in Figure $5 \mathrm{~b}$. It was observed that the magnetization curves were performed S-shaped with the applied magnetic field and the saturation magnetization (Ms) were found to be $48.50 \mathrm{emu} / \mathrm{g}$ and $34.39 \mathrm{emu} / \mathrm{g}$ for $\mathrm{CoFe}_{2} \mathrm{O}_{4}$ nanoparticles and the $\mathrm{CoFe}_{2} \mathrm{O}_{4} @ \mathrm{DHBF}$ respectively. In the case of the $\mathrm{CoFe}_{2} \mathrm{O}_{4} @ \mathrm{DHBF}$, the magnetization was decreased due the nonmagnetic weight ratio of the polymer, DHBF. Hence, the $\mathrm{CoFe}_{2} \mathrm{O}_{4} @ \mathrm{DHBF}$ contains enough magnetization and could be easily and rapidly separated from aqueous solution using a magnet in a very short time. 

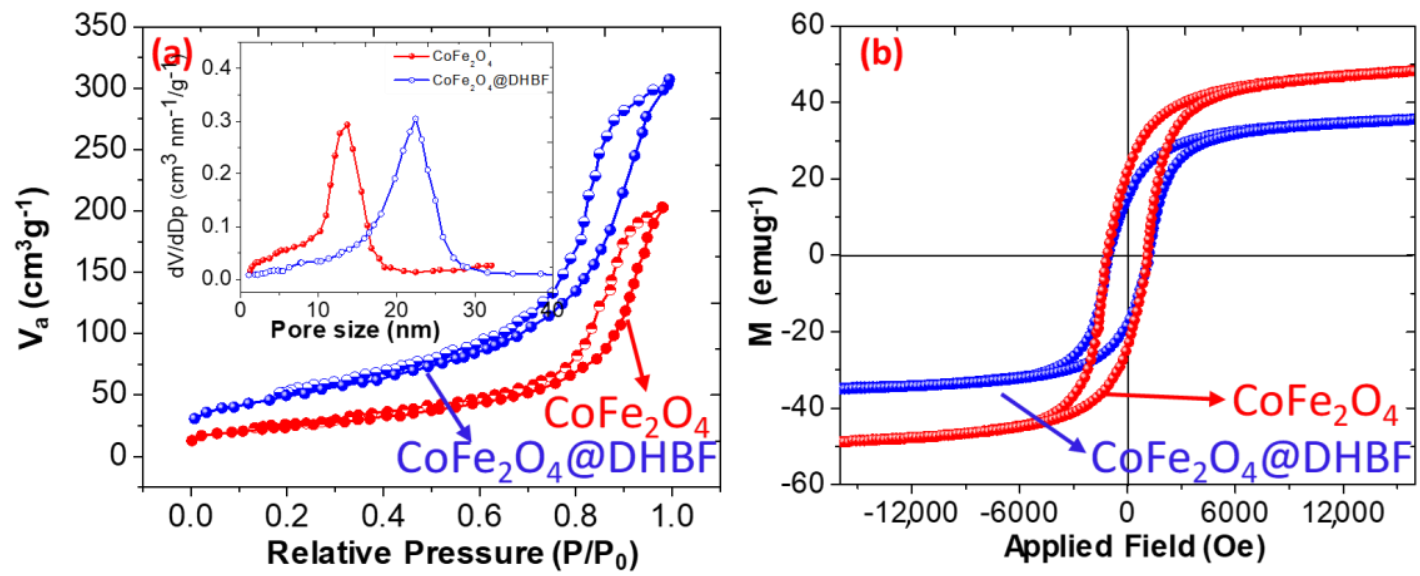

Figure 5. (a) $\mathrm{N}_{2}$ adsorption and desorption of $\mathrm{CoFe}_{2} \mathrm{O}_{4}$ and $\mathrm{CoFe}_{2} \mathrm{O}_{4} @ D H B F(b)$ magnetic measurements $\mathrm{CoFe}_{2} \mathrm{O}_{4}$ and $\mathrm{CoFe}_{2} \mathrm{O}_{4} @ \mathrm{DHBF}$.

\subsection{Batch Adsorption of the Radioactive Ions}

\subsubsection{Effect of $\mathrm{pH}$, Initial Concentration, Initial Contact Time}

The effect of the $\mathrm{pH}$, initial concentration of $\mathrm{U}(\mathrm{VI})$ and $\mathrm{Eu}(\mathrm{III})$, the dose of the $\mathrm{CoFe}_{2} \mathrm{O}_{4} @ \mathrm{DHBF}$ and the effect of contact time on the removal was thoroughly studied. The $\mathrm{pH}$ of the solution is one of the important factor for the removal of the metal ions one $\mathrm{CoFe}_{2} \mathrm{O}_{4} @ \mathrm{DHBF}$ [58]. It was noticed, when the $\mathrm{pH}$ of the solution was increased from 2 to 7 the percentage adsorption was increased and found to be 95\% and 92.2\% (with adsorption capacity 237.5 and $225.5 \mathrm{mg} / \mathrm{g}$ ) with U(VI) and Eu(III) respectively as display in Figure 6a. Therefore, $\mathrm{CoFe}_{2} \mathrm{O}_{4} @ \mathrm{DHBF}$ has excellent adsorption performance for both the metals, and was far superior most conventional adsorbents listed in Supplementary Table S2. To understand the effect of the $\mathrm{pH}$ for the removal of the metal ions $\mathrm{pH}_{\mathrm{pzc}}$ was determined because the adsorbent surface zeta potential significantly influenced the removal of heavy metal. As shown in Supplementary Figure S1, the $\mathrm{pH}_{\mathrm{pzc}}$ of the $\mathrm{CoFe}_{2} \mathrm{O}_{4} @ \mathrm{DHBF}$ was found to be 5.13. Therefore, at $\mathrm{pH}<\mathrm{pH}_{\mathrm{pzc}}$ (point of zero charge), the surface charge of the nanocomposite was positive due to extra protons $\left(\mathrm{H}^{+}\right)$, thus the struggle with the metal ions to bind with the adsorption sites, resulting in the active sites of $\mathrm{CoFe}_{2} \mathrm{O}_{4} @ \mathrm{DHBF}$ being protonated and the adsorption capacity for the adsorption of metal ions decreasing due to the presence of extra protons. Moreover, the maximum adsorption was noticed at $\mathrm{pH} 7$. However, when the $\mathrm{pH}$ of the solution was further increased, the adoration capacity was decreased due to the formation of the insoluble hydroxide of the corresponding metal ions. The contact time of the adsorbent with the adsorbate affects the adsorption of both the metal ions on $\mathrm{CoFe}_{2} \mathrm{O}_{4} @$ DHBF. As shown in Figure 6b, the adsorption of both the metal ions at different time form $5 \mathrm{~min}$ to $200 \mathrm{~min}$ were studied. It was noticed that the contact time between both U(VI) and $\mathrm{Eu}(\mathrm{III})$ increased and the adsorption of both the metal ions increased initially within $30 \mathrm{~min}$, when about $77.9 \%$ and $74.0 \%$ of $\mathrm{U}(\mathrm{VI})$ and $\mathrm{Eu}(\mathrm{III})$ were adsorbed. When the contact time was increased to $60 \mathrm{~min}$, it reaches equilibrium and about 237.5 and $225.5 \mathrm{mg} / \mathrm{g}$ adsorption capacity was noticed against the U(VI) and $\mathrm{Eu}(\mathrm{III})$ respectively. However, increasing the time further only slightly changed the adsorption capacity. The effects of the initial concentration during the adsorption of the metal ions on to $\mathrm{CoFe}_{2} \mathrm{O}_{4} @ \mathrm{DHBF}$ was investigated at varying initial concentration from 5-300 mg/L and the results were illustrated in Figure 6c. It was noticed that, when the initial concentration of both the U(VI) and Eu(III) ions was increased, the adsorption percentage of was decreased, while the adsorption capacity of the $\mathrm{CoFe}_{2} \mathrm{O}_{4} @ \mathrm{DHBF}$ was increased with the initial concentration [59]. Resulting, the initial concentration of $100 \mathrm{mg} / \mathrm{L}$ show the highest percentage adsorption and were found to be 237.5 and $225.5 \mathrm{mg} / \mathrm{g}$ with $\mathrm{U}(\mathrm{VI})$ and $\mathrm{Eu}(\mathrm{III})$ respectively within $60 \mathrm{~min}$. Additionally, for the industrial application, the adsorption of both the metal ions at their lower concentration in the range $(0.05$ to $2 \mathrm{mg} / \mathrm{L}$ ) were also observed and the results are illustrated in Supplementary Figure S2. The results 
revealed that the adsorption percentage of both metal ions was increased with decreasing concentration in both the case distilled water and in synthetic wastewater. Moreover, these results revealed that the adsorption of metal ions slightly decreased in the case of the synthetic wastewater sample due to the presence of co-existence ions.
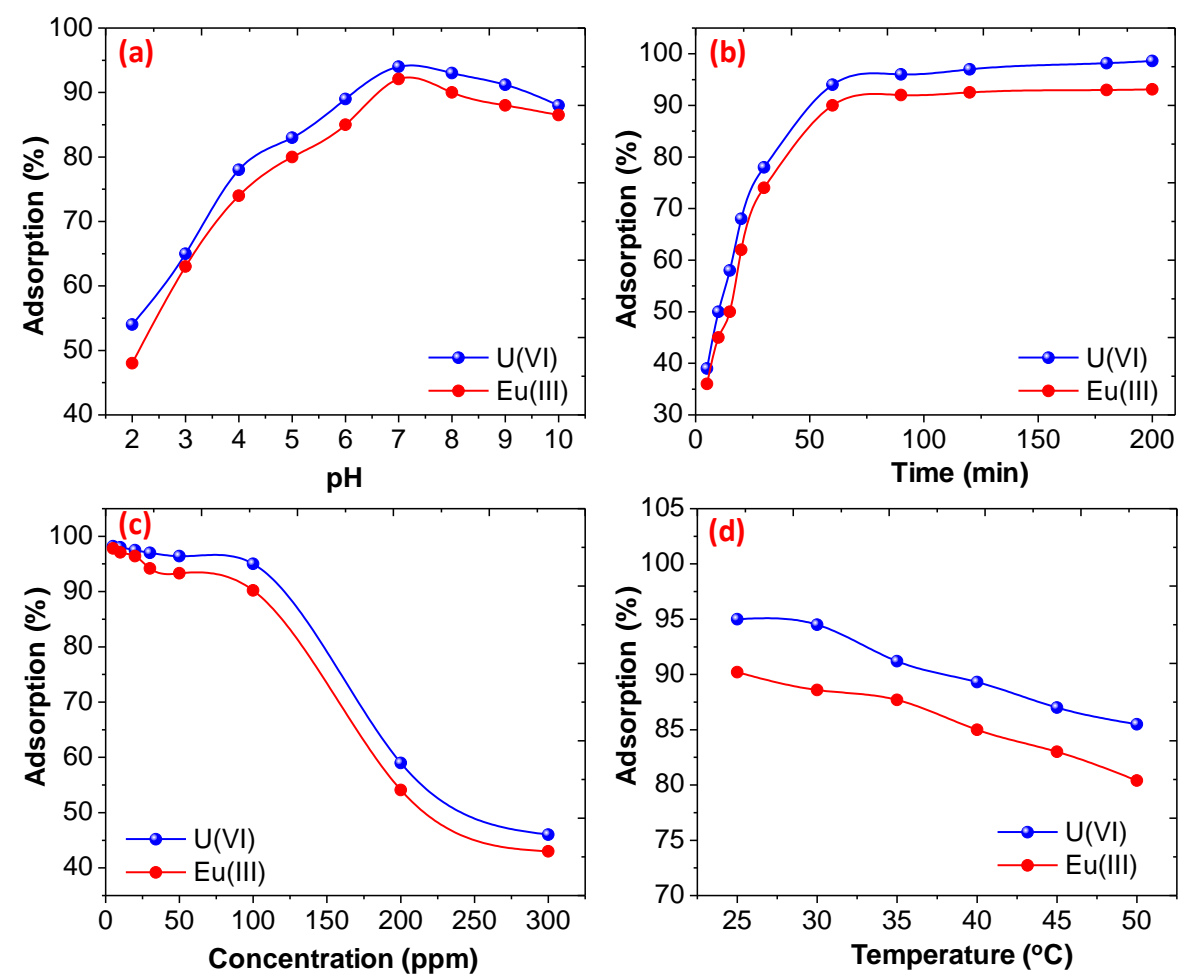

Figure 6. Effect of (a) $\mathrm{pH}(\mathbf{b})$ time (c) initial concentration and (d) temperature on the adsorption of $\mathrm{U}(\mathrm{VI})$ and $\mathrm{Eu}(\mathrm{III})$ onto $\mathrm{CoFe}_{2} \mathrm{O}_{4} @ \mathrm{DHBF}$ (dose $=0.01 \mathrm{~g}, 25 \mathrm{~mL}, \mathrm{pH}=7$, concentration $100 \mathrm{mg} / \mathrm{L}$, time $60 \mathrm{~min}$ at room temperature).

Initially, the adsorption capacity was increased with the initial concentration. This is because the contact between metal ions and the adsorptive sites of $\mathrm{CoFe}_{2} \mathrm{O}_{4} @ \mathrm{DHBF}$ was increased. However, at high initial concentration, the availability of the adsorptive sites of $\mathrm{CoFe}_{2} \mathrm{O}_{4} @ \mathrm{DHBF}$ were regularly decreased and the saturation took place, resulting in a decreased adsorption capacity with both the metal ions. Moreover, the effects of temperature for the adsorption of both the metal ions were also investigated and the results are displayed in Figure $6 \mathrm{~d}$. The adsorption results revealed that the adsorption of both the metal ions was decreased with increasing the temperature of the aqueous solution. Therefore, room temperature is suitable for the adsorption of both the metal ions and was used as an optimum temperature.

\subsubsection{Adsorption Isotherms}

To determine the interaction and the adsorption mechanism for the adsorption of $\mathrm{U}(\mathrm{VI})$ and $\mathrm{Eu}(\mathrm{III})$ onto $\mathrm{CoFe}_{2} \mathrm{O}_{4} @ \mathrm{DHBF}$, absorption isotherm including Langmuir, Freundlich and Temkin models have been used (the details of adsorption isotherms are given in the Supplementary Materials) [60-62]. The nonlinear fittings for these models are displayed in Figure 7, and the results are summarized in Table 1. The results revealed that the experimental data are well fitted with the Langmuir isotherm model and the correlation coefficient $\left(\mathrm{R}^{2}\right)$ values were found to be 0.9920 and 0.9913 for the adsorption of $\mathrm{U}(\mathrm{VI})$ and $\mathrm{Eu}(\mathrm{III})$, respectively. The calculated adsorption capacity was found to be $330.63 \mathrm{mg} / \mathrm{g}$ and $310.70 \mathrm{mg} / \mathrm{g}$ with $\mathrm{U}(\mathrm{VI})$ and $\mathrm{Eu}(\mathrm{III})$ respectively, which were closed to the experimental values at room temperature $(298 \mathrm{~K})$. Additionally, the effects of temperature on the adsorption isotherm were also evaluated and the results revealed that, at the increased temperature, the adsorption of both the metal 
ions was decreased. These outcomes support the fact that adsorption followed the Langmuir isotherm and homogenous monolayers adsorption due to the chemisorption between both the metal ions.
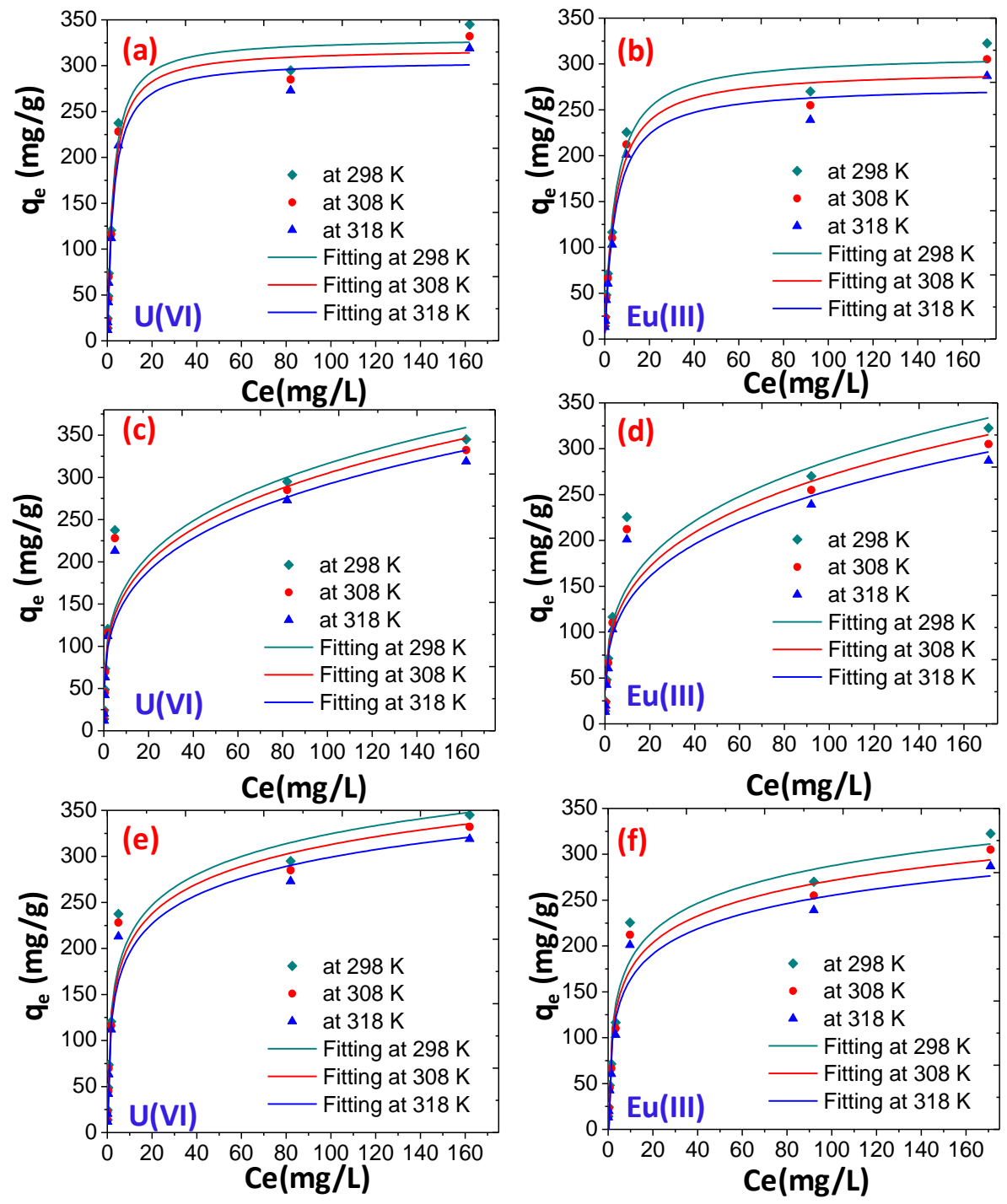

Figure 7. Non-linear fitting for the adsorption of $\mathrm{U}(\mathrm{VI})$ and $\mathrm{Eu}(\mathrm{III})(\mathbf{a}, \mathbf{b})$ Langmuir $(\mathbf{c}, \mathbf{d})$ Freundlich $(\mathbf{e}, \mathbf{f})$ Temkin isotherm (dose $=0.01 \mathrm{~g}, 25 \mathrm{~mL}, \mathrm{pH}=7$, time $60 \mathrm{~min}$ at room temperature).

Table 1. Adsorption isotherm parameters for the adsorption of $\mathrm{U}(\mathrm{VI})$ and $\mathrm{Eu}(\mathrm{III})$ on $\mathrm{CoFe}_{2} \mathrm{O}_{4} @ \mathrm{DHBF}$ (dose $=0.01 \mathrm{~g}, 25 \mathrm{~mL}, \mathrm{pH}=7$, time $60 \mathrm{~min}$ at room temperature).

\begin{tabular}{|c|c|c|c|c|c|}
\hline \multirow{2}{*}{ Metal Ions } & \multirow{2}{*}{ Isotherm Models } & \multirow{2}{*}{ Parameters } & \multicolumn{3}{|c|}{ Temperature $\left({ }^{\circ} \mathrm{C}\right)$} \\
\hline & & & 25 & 35 & 45 \\
\hline \multirow{9}{*}{$\mathrm{U}(\mathrm{VI})$} & \multirow{3}{*}{ Langmuir model } & $q_{\mathrm{m}}\left(\mathrm{mg} \cdot \mathrm{g}^{-1}\right)$ & 330.63 & 319.01 & 3.5.81 \\
\hline & & $K_{\mathrm{L}}\left(\mathrm{L} \cdot \mathrm{mg}^{-1}\right)$ & 0.3940 & 0.3879 & 0.3730 \\
\hline & & $R^{2}$ & 0.9920 & 0.9929 & 0.9952 \\
\hline & \multirow{3}{*}{ Freundlich model } & $K_{\mathrm{f}}\left(\mathrm{mg}^{1-1 / \mathrm{n}} \cdot \mathrm{L}^{1 / \mathrm{n}} \cdot \mathrm{g}^{-1}\right)$ & 94.24 & 90.03 & 89.46 \\
\hline & & $n$ & 3.80 & 3.77 & 3.71 \\
\hline & & $R^{2}$ & 0.8670 & 0.8669 & 0.8750 \\
\hline & \multirow{3}{*}{ Temkinmodel } & $K_{t}(\mathrm{~L} / \mathrm{g})$ & 8.31 & 8.10 & 7.76 \\
\hline & & $B_{t}$ & 48.27 & 46.71 & 44.95 \\
\hline & & $R^{2}$ & 0.9579 & 0.9487 & 0.9643 \\
\hline
\end{tabular}


Table 1. Cont

\begin{tabular}{cccccc}
\hline \multirow{2}{*}{ Metal Ions } & \multirow{2}{*}{ Isotherm Models } & \multirow{2}{*}{ Parameters } & \multicolumn{3}{c}{ Temperature $\left({ }^{\circ} \mathbf{C}\right)$} \\
\cline { 3 - 6 } & & & $\mathbf{2 5}$ & $\mathbf{3 5}$ & $\mathbf{4 5}$ \\
\hline \multirow{3}{*}{ Langmuir model } & $q_{\mathrm{m}}\left(\mathrm{mg}^{-1} \mathrm{~g}^{-1}\right)$ & 310.70 & 293.72 & 276.40 \\
& & $K_{\mathrm{L}}\left(\mathrm{L} \cdot \mathrm{mg}^{-1}\right)$ & 0.2152 & 0.2132 & 0.2113 \\
& & $R^{2}$ & 0.9913 & 0.9912 & 0.9901 \\
\cline { 3 - 6 } Eu (III) & \multirow{2}{*}{ Freundlich model } & $K_{\mathrm{f}}\left(\mathrm{mg}^{1-1 / \mathrm{n}} \cdot \mathrm{L}^{1 / \mathrm{n}} \cdot \mathrm{g}^{-1}\right)$ & 77.76 & 73.19 & 68.34 \\
& & $n$ & 3.53 & 3.52 & 3.50 \\
& & $R^{2}$ & 0.8969 & 0.9010 & 0.8967 \\
\cline { 3 - 6 } & \multirow{3}{*}{ Temkinmodel } & $K_{t}(\mathrm{~L} / \mathrm{g})$ & 6.34 & 6.32 & 6.19 \\
& & $B_{t}$ & 44.54 & 42.06 & 39.67 \\
& & $R^{2}$ & 0.9478 & 0.9472 & 0.9439 \\
\hline
\end{tabular}

To determine the adsorption rate and adsorption rate constant the adsorption kinetics during the adsorption of $\mathrm{U}(\mathrm{VI})$ and $\mathrm{Eu}(\mathrm{III})$ on to $\mathrm{CoFe}_{2} \mathrm{O}_{4} @ \mathrm{DHBF}$ was determine using pseudo-first order, pseudo-second order, and interparticle diffusion method and the experimental data was fitted with non-liner model $[19,63,64]$. The resulting adsorption kinetics parameters were summarized into Table 2. As shown in Figure 8a,b, the pseudo-second order model is well fitted and correlates with the experimental results, the correlation coefficient $\left(R^{2}\right)$ value was found to be close to $1(0.9907)$. Meanwhile, in the case of pseudo-first order and interparticle diffusion, the values of $R^{2}$ were found to be 0.9510 and 0.9514 , respectively, during the adsorption of $\mathrm{U}(\mathrm{VI})$. The maximum adsorption capacity $\left(\mathrm{q}_{\mathrm{e}}\right.$ ) was determine using pseudo-second order model and found to be $263.89 \mathrm{mg} / \mathrm{g}$ and $253.31 \mathrm{mg} / \mathrm{g}$ with $\mathrm{U}(\mathrm{VI})$ and $\mathrm{Eu}(\mathrm{III})$, these values are close to the experimental values. These outcomes support that the adsorption of both the metal ions were follow the pseudo-second order kinetics model and the adsorption capacity of both the metal ions remain constant with time after equilibrium and the available active sites for adsorption depends on the concentration of the metal ions at equilibrium. The adsorption of both the metal ions was chemisorption and the interaction between both the metal ions and the $\mathrm{CoFe}_{2} \mathrm{O}_{4} @ \mathrm{DHBF}$ via coordination of electrons and the covenant.

Table 2. Adsorption kinetic parameters for the adsorption of $\mathrm{U}(\mathrm{VI})$ and $\mathrm{Eu}(\mathrm{III})$ on $\mathrm{CoFe}_{2} \mathrm{O}_{4} @ \mathrm{DHBF}$.

\begin{tabular}{|c|c|c|c|}
\hline Metal Ions & Kinetic Models & Parameter & \\
\hline \multirow{3}{*}{ U(VI) } & PFO model & $\begin{array}{l}\mathrm{q}_{\mathrm{e}}\left(\mathrm{mg} \cdot \mathrm{g}^{-1}\right) \\
\mathrm{k}_{1}\left(\min ^{-1}\right) \\
\mathrm{R}^{2}\end{array}$ & $\begin{array}{c}241.16 \\
0.067 \\
0.9510\end{array}$ \\
\hline & PSO model & $\begin{array}{c}\mathrm{qe}_{\mathrm{e}}\left(\mathrm{mg} \cdot \mathrm{g}^{-1}\right) \\
\mathrm{k}_{2}\left(\mathrm{~g} \cdot \mathrm{mg}^{-1} \cdot \mathrm{min}^{-1}\right) \\
\mathrm{R}^{2}\end{array}$ & $\begin{array}{c}263.89 \\
3.61 \times 10^{-4} \\
0.9907\end{array}$ \\
\hline & Intra-particle diffusion & $\begin{array}{c}\mathrm{C} \\
\mathrm{K}_{\text {dif }}\left(\mathrm{mg} \mathrm{g}^{-1} \min ^{-1 / 2}\right) \\
\mathrm{R}^{2}\end{array}$ & $\begin{array}{c}106.15 \\
11.77 \\
0.9514\end{array}$ \\
\hline \multirow{3}{*}{$\mathrm{Eu}(\mathrm{III})$} & PFO model & $\begin{array}{l}\mathrm{q}_{\mathrm{e}}\left(\mathrm{mg} \cdot \mathrm{g}^{-1}\right) \\
\mathrm{k}_{1}\left(\min ^{-1}\right) \\
\mathrm{R}^{2}\end{array}$ & $\begin{array}{c}230.31 \\
0.060 \\
0.9524\end{array}$ \\
\hline & PSO model & $\begin{array}{c}\mathrm{q}_{\mathrm{e}}\left(\mathrm{mg} \cdot \mathrm{g}^{-1}\right) \\
\mathrm{k}_{2}\left(\mathrm{~g} \cdot \mathrm{mg}^{-1} \cdot \mathrm{min}^{-1}\right) \\
\mathrm{R}^{2}\end{array}$ & $\begin{array}{c}253.31 \\
3.30 \times 10^{-4} \\
0.9912\end{array}$ \\
\hline & Intra-particle diffusion & $\frac{\mathrm{C}}{\mathrm{K}_{\text {dif }}\left(\mathrm{mg} \mathrm{g}^{-1} \min ^{-1 / 2}\right)}$ & $\begin{array}{c}93.58 \\
11.78 \\
0.8795\end{array}$ \\
\hline
\end{tabular}



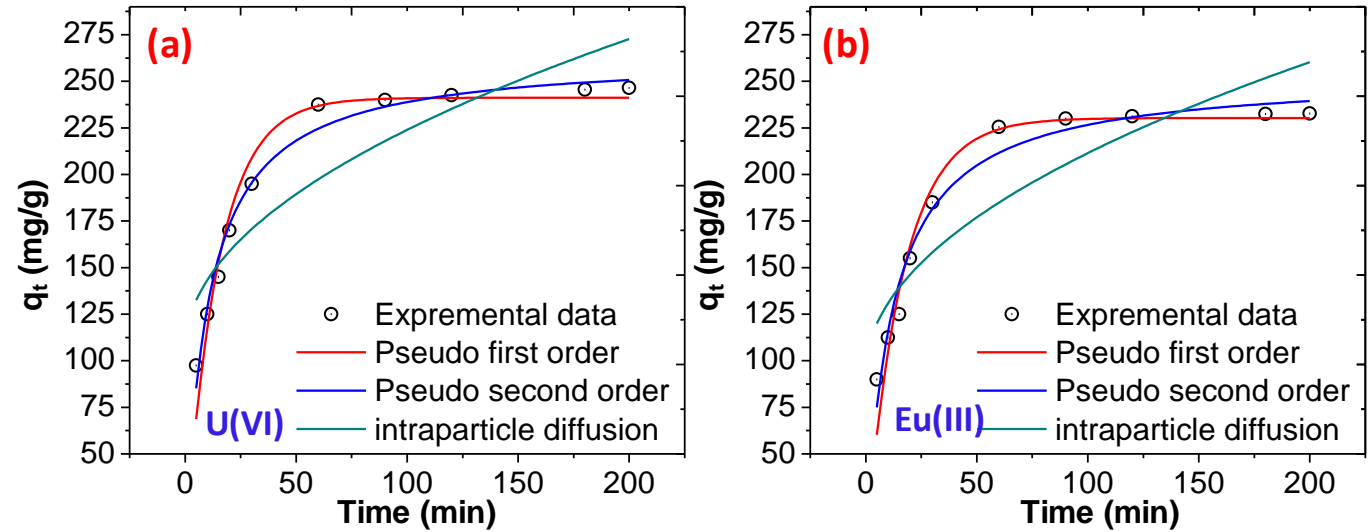

Figure 8. (a) Adsorption kinetics for the adsorption of U(VI) (b) adsorption kinetics for the adsorption of $\mathrm{Eu}(\mathrm{III})$ (dose $=0.01 \mathrm{~g}, 25 \mathrm{~mL}, \mathrm{pH}=7$, concentration $100 \mathrm{mg} / \mathrm{L}$, at room temperature).

The thermodynamics parameters, including change in enthalpy $(\Delta \mathrm{H})$, change in entropy $(\Delta \mathrm{S})$, and the Gibbs free energy $(\Delta \mathrm{G})$, during the adsorption of $\mathrm{U}(\mathrm{VI})$ and $\mathrm{Eu}(\mathrm{III})$ were determined using the van't Hoff equation and the details are given in supplementary information $[65,66]$. The results are illustrated in Figure 9a, and they reveal that the adsorption of both the metal ions proceeds via an exothermic reaction and the negative value of the $\Delta G$ supports the spontaneous reaction. The values of $\Delta \mathrm{G}$ increased with the temperature of the solution and the results are summarized in Table 3.
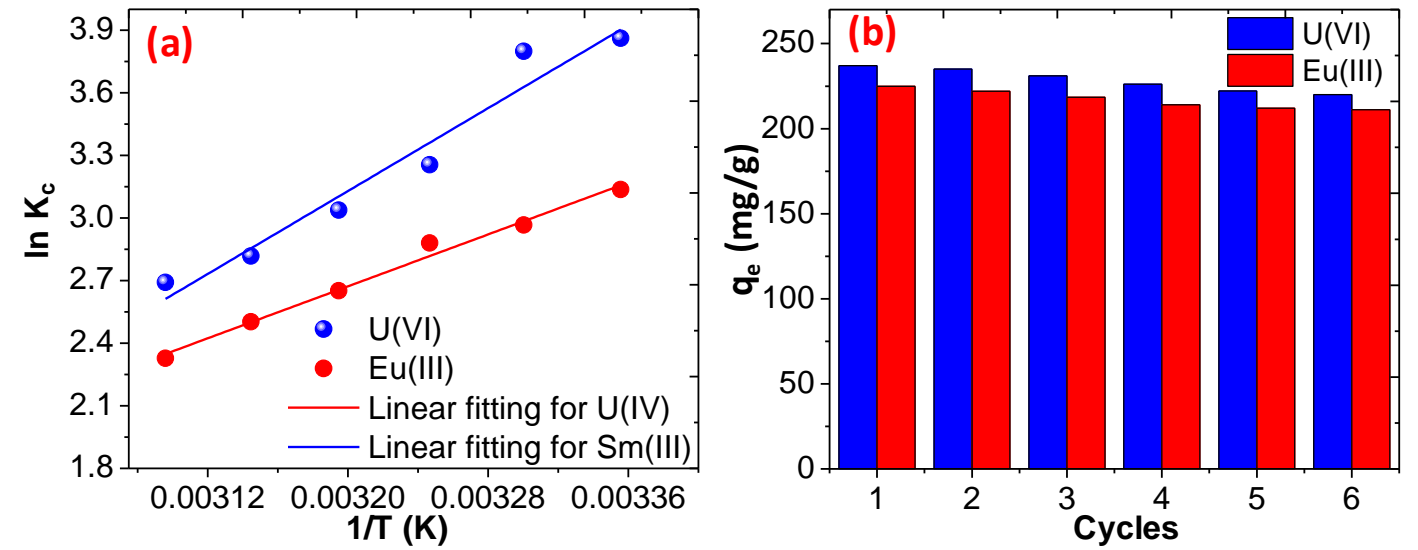

Figure 9. (a) adsorption thermodynamic of $\mathrm{U}(\mathrm{VI})$ and $\mathrm{Eu}(\mathrm{III})$ over $\mathrm{CoFe}_{2} \mathrm{O}_{4} @ \mathrm{DHBF}(\mathbf{b})$ regeneration behavior of $\mathrm{CoFe}_{2} \mathrm{O}_{4} @ \mathrm{DHBF}$ (dose $=0.01 \mathrm{~g}, 25 \mathrm{~mL}, \mathrm{pH}=7$, concentration $100 \mathrm{mg} / \mathrm{L}$, time 60).

Table 3. Thermodynamic parameters for the adsorption of $\mathrm{U}(\mathrm{VI})$ and $\mathrm{Eu}(\mathrm{III})$ on $\mathrm{CoFe}_{2} \mathrm{O}_{4} @ \mathrm{DHBF}$.

\begin{tabular}{|c|c|c|c|c|c|c|}
\hline \multirow{2}{*}{$\begin{array}{c}\text { Temperature } \\
\text { (K) }\end{array}$} & \multicolumn{3}{|c|}{ U(VI) } & \multicolumn{3}{|c|}{ Eu(III) } \\
\hline & $\begin{array}{c}\text { Entropy } \\
(\Delta S)\end{array}$ & $\begin{array}{c}\text { Enthalpy } \\
(\Delta \mathrm{H})\end{array}$ & $\begin{array}{c}\text { Gibbs Free } \\
\text { Energy }(\Delta G)\end{array}$ & $\begin{array}{c}\text { Entropy } \\
(\Delta S)\end{array}$ & $\begin{array}{c}\text { Enthalpy } \\
(\Delta \mathrm{H})\end{array}$ & $\begin{array}{c}\text { Gibbs Free } \\
\text { Energy }(\Delta G)\end{array}$ \\
\hline 298 & -0.0605 & -25.87 & -7.82 & -0.107 & -41.79 & -9.64 \\
\hline 303 & -0.0605 & -25.87 & -7.51 & -0.107 & -41.79 & -9.10 \\
\hline 308 & -0.0605 & -25.87 & -7.21 & -0.107 & -41.79 & -8.56 \\
\hline 313 & -0.0605 & -25.87 & -6.91 & -0.107 & -41.79 & -8.02 \\
\hline 318 & -0.0605 & -25.87 & -6.60 & -0.107 & -41.79 & -7.48 \\
\hline 323 & -0.0605 & -25.87 & -6.30 & -0.107 & -41.79 & -6.94 \\
\hline
\end{tabular}

\subsection{Reusability and Regeneration Ability}

The reusability and regeneration of the $\mathrm{CoFe}_{2} \mathrm{O}_{4} @ \mathrm{DHBF}$ was carried out with six cycles and the results are illustrated in Figure 9b. It was noticed that the fabricated nanocomposites show excellent 
regeneration ability and about to 220.1 and $211.3 \mathrm{mg} / \mathrm{g}$ adsorption capacity remains with $\mathrm{U}(\mathrm{VI})$ and $\mathrm{Eu}(\mathrm{III})$ under optimum conditions $(\mathrm{pH}=7$, room temperature, initial concentration $100 \mathrm{mg} / \mathrm{L}$, dose of adsorbent $0.01 \mathrm{~g}$, volume $25 \mathrm{~mL}$ ) $[67,68]$. The slow decrease in the adsorption capacity with each cycle of regeneration may be due to the loss of the adsorbent during the regeneration because no change in the adsorption site was noticed and supported by the XPS spectra after 3 cycles as shown in Supplementary Figure S3. These outcomes revealed that the $\mathrm{CoFe}_{2} \mathrm{O}_{4} @ \mathrm{DHBF}$ exhibits promising regeneration ability for the adsorption of both the metal ions and in future can be used as a potential adsorbent for the adsorption of toxic pollutants form aqueous solution on an industrial scale.

\section{Conclusions}

Herein, we have fabricated novel nanocomposite and characterized successfully. As-prepared nanocomposite was utilized as capable adsorbent for the removal of $\mathrm{U}(\mathrm{VI})$ and $\mathrm{Eu}(\mathrm{III})$ form contaminated water. The batch adsorption results exposed that the adsorption capacity for the removal of U(VI) and $\mathrm{Eu}(\mathrm{III})$ was found to be 237.5 and $225.5 \mathrm{mg} / \mathrm{g}$, respectively, at room temperature. The optimum condition of the adsorption of both metal ions were $\mathrm{pH}=7$, initial concentration $100 \mathrm{mg} / \mathrm{L}$, contact time $60 \mathrm{~min}$, and room temperature. The interaction between the metal ions and the $\mathrm{CoFe}_{2} \mathrm{O}_{4} @ \mathrm{DHBF}$ was determine using the adsorption isotherm and adsorption kinetics. The adsorption of both the metals followed the pseudo-second order reaction model and Langmuir adsorption isotherm. The correlation coefficient $\left(R^{2}\right)$ values of the Langmuir isotherm were found to be 0.9920 and 0.9913 for the adsorption of $\mathrm{U}(\mathrm{VI})$ and $\mathrm{Eu}(\mathrm{III})$, respectively. Additionally, the reusability results exhibit promising regeneration ability for the adsorption of both the metal ions and in future can be used as a potential adsorbent for the adsorption of toxic pollutants form aqueous solution on industrial scale.

Supplementary Materials: The following are available online at http://www.mdpi.com/2073-4360/12/12/2940/s1, Table S1: A comparison of removal technologies for the removal of radioactive metal ions, Figure S1: Zeta potential of synthesized CoFe2O4@DHBF, Figure S2: (a) Effect of initial concentration for the adsorption of U(VI) and Eu(III) onto CoFe2O4@DHBF (in distilled water) (b) Effect of initial concentration for the adsorption of U(VI) and Eu(III) onto CoFe2O4@DHBF (in synthetic wastewater) $(0.01 \mathrm{~g}$ adsorbent, $25 \mathrm{~mL}$, optimum pH = 7, optimum time $60 \mathrm{~min}$ at room temperature), Table S2: Comparison of adsorption capacities of Eu(III) and U(VI) by various adsorbents, Figure S3: XPS spectra after adsorption of U(VI) and Eu(III) and after desorption 3 cycles.

Author Contributions: Conceptualization, T.A. and M.N.; methodology, T.A. and S.A.; software, M.U.; validation, T.A., S.A. and M.U.; formal analysis, T.A. and M.N.; investigation, T.A.; resources, S.A.; data curation, T.A. and M.N.; writing-original draft preparation, T.A. and M.U.; writing-review and editing, T.A. and M.U.; visualization, M.U.; supervision, T.A.; project administration, T.A.; funding acquisition, T.A. All authors have read and agreed to the published version of the manuscript.

Funding: This research was funded by Deputyship for Research \& Innovation, "Ministry of Education" in Saudi Arabia, grant number IFKSURG-1438-026.

Acknowledgments: The authors extend their appreciation to the Deputyship for Research \& Innovation, "Ministry of Education" in Saudi Arabia for funding this research work through the project number IFKSURG-1438-026.

Conflicts of Interest: The authors declare no conflict of interest.

\section{References}

1. Alqadami, A.A.; Naushad, M.; Alothman, Z.A.; Ghfar, A.A. Novel Metal-Organic Framework (MOF) Based Composite Material for the Sequestration of U(VI) and Th(IV) Metal Ions from Aqueous Environment. ACS Appl. Mater. Interfaces 2017, 9, 36026-36037. [CrossRef] [PubMed]

2. Asic, A.; Kurtovic-Kozaric, A.; Besic, L.; Mehinovic, L.; Hasic, A.; Kozaric, M.; Hukic, M.; Marjanovic, D. Chemical toxicity and radioactivity of depleted uranium: The evidence from in vivo and in vitro studies. Environ. Res. 2017, 156, 665-673. [CrossRef] [PubMed]

3. Bai, Z.Q.; Yuan, L.Y.; Zhu, L.; Liu, Z.R.; Chu, S.Q.; Zheng, L.R.; Zhang, J.; Chai, Z.F.; Shi, W.Q. Introduction of amino groups into acid-resistant MOFs for enhanced U(vi) sorption. J. Mater. Chem. A 2015, 3, 525-534. [CrossRef] 
4. Chen, L.; Yu, X.; Zhao, Z. Effect of humic acid, pH and ionic strength on the sorption of Eu(III) on red earth and its solid component. J. Radioanal. Nucl. Chem. 2007, 274, 187-193. [CrossRef]

5. Dai, S.; Wang, N.; Qi, C.; Wang, X.; Ma, Y.; Yang, L.; Liu, X.; Huang, Q.; Nie, C.; Hu, B.; et al. Preparation

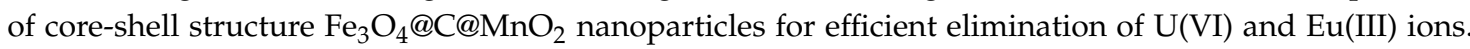
Sci. Total Environ. 2019, 685, 986-996. [CrossRef]

6. Guo, W.; Nie, C.; Wang, L.; Li, Z.; Zhu, L.; Zhu, L.; Zhu, Z.; Shi, W.; Yuan, L. Easily prepared and stable functionalized magnetic ordered mesoporous silica for efficient uranium extraction. Sci. China Chem. 2016, 59, 629-636. [CrossRef]

7. Huang, S.; Pang, H.; Li, L.; Jiang, S.; Wen, T.; Zhuang, L.; Hu, B.; Wang, X. Unexpected ultrafast and high adsorption of $\mathrm{U}(\mathrm{VI})$ and $\mathrm{Eu}(\mathrm{III})$ from solution using porous $\mathrm{A} 12 \mathrm{O} 3$ microspheres derived from MIL-53. Chem. Eng. J. 2018, 353, 157-166. [CrossRef]

8. Huang, Z.; Li, Z.; Zheng, L.; Zhou, L.; Chai, Z.; Wang, X.; Shi, W. Interaction mechanism of uranium(VI) with three-dimensional graphene oxide-chitosan composite: Insights from batch experiments, IR, XPS, and EXAFS spectroscopy. Chem. Eng. J. 2017, 328, 1066-1074. [CrossRef]

9. Huang, Z.W.; Li, Z.J.; Wu, Q.Y.; Zheng, L.R.; Zhou, L.M.; Chai, Z.F.; Wang, X.L.; Shi, W.Q. Simultaneous elimination of cationic uranium(vi) and anionic rhenium(vii) by graphene oxide-poly(ethyleneimine) macrostructures: A batch, XPS, EXAFS, and DFT combined study. Environ. Sci. Nano 2018, 5, 2077-2087. [CrossRef]

10. Dao, T.-H.; Vu, T.-Q.-M.; Nguyen, N.-T.; Pham, T.-T.; Nguyen, T.-L.; Yusa, S.-I.; Pham, T.-D. Adsorption Characteristics of Synthesized Polyelectrolytes onto Alumina Nanoparticles and their Application in Antibiotic Removal. Langmuir 2020, 36, 13001-13011. [CrossRef]

11. Nguyen, N.T.; Dao, T.H.; Truong, T.T.; Nguyen, T.M.T.; Pham, T.D. Adsorption characteristic of ciprofloxacin antibiotic onto synthesized alpha alumina nanoparticles with surface modification by polyanion. J. Mol. Liq. 2020, 309, 113150. [CrossRef]

12. Pham, T.D.; Bui, T.T.; Trang Truong, T.T.; Hoang, T.H.; Le, T.S.; Duong, V.D.; Yamaguchi, A.; Kobayashi, M.; Adachi, Y. Adsorption characteristics of beta-lactam cefixime onto nanosilica fabricated from rice HUSK with surface modification by polyelectrolyte. J. Mol. Liq. 2020, 298, 111981. [CrossRef]

13. Dao, T.H.; Nguyen, N.T.; Nguyen, M.N.; Ngo, C.L.; Luong, N.H.; Le, D.B.; Pham, T.D. Adsorption behavior of polyelectrolyte onto alumina and application in ciprofloxacin removal. Polymers 2020, 12, 1554. [CrossRef] [PubMed]

14. Mathews, T.; Beaugelin-Seiller, K.; Garnier-Laplace, J.; Gilbin, R.; Adam, C.; Della-Vedova, C. A probabilistic assessment of the chemical and radiological risks of chronic exposure to uranium in freshwater ecosystems. Environ. Sci. Technol. 2009, 43, 6684-6690. [CrossRef] [PubMed]

15. Ordoñez-Regil, E.; Ortíz-Oliveros, H.B.; Fernández-Valverde, S.M.; Granados-Correa, F. Eu (III) sorption from an aqueous solution onto $\mathrm{SrTiO}_{3}$ and surface complex behavior. Chem. Eng. J. 2014, 254, 349-356. [CrossRef]

16. Pham, T.D.; Tran, T.T.; Le, V.A.; Pham, T.T.; Dao, T.H.; Le, T.S. Adsorption characteristics of molecular oxytetracycline onto alumina particles: The role of surface modification with an anionic surfactant. J. Mol. Liq. 2019, 287, 110900. [CrossRef]

17. Ahamad, T.; Naushad, M.; Al-Shahrani, T.; Al-hokbany, N.; Alshehri, S.M. Preparation of chitosan based magnetic nanocomposite for tetracycline adsorption: Kinetic and thermodynamic studies. Int. J. Biol. Macromol. 2020, 147, 258-267. [CrossRef]

18. Ahamad, T.; Ruksana; Chaudhary, A.A.; Naushad, M.; Alshehri, S.M. Fabrication of $\mathrm{MnFe}_{2} \mathrm{O}_{4}$ nanoparticles embedded chitosan-diphenylureaformaldehyde resin for the removal of tetracycline from aqueous solution. Int. J. Biol. Macromol. 2019, 134, 180-188. [CrossRef]

19. Ahamad, T.; Naushad, M.; Eldesoky, G.E.; Alqadami, A.A.; Khan, A. Synthesis and characterization of egg-albumen-formaldehyde based magnetic polymeric resin (MPR): Highly efficient adsorbent for Cd(II) ion removal from aqueous medium. J. Mol. Liq. 2019, 286, 110951. [CrossRef]

20. Naushad, M.; Alqadami, A.A.; Ahamad, T. Removal of Cd(II) ion from aqueous environment using triaminotriethoxysilane grafted oxidized activated carbon synthesized via activation and subsequent silanization. Environ. Technol. Innov. 2020, 18, 100686. [CrossRef] 
21. Wang, X.; Chen, L.; Wang, L.; Fan, Q.; Pan, D.; Li, J.; Chi, F.; Xie, Y.; Yu, S.; Xiao, C.; et al. Synthesis of novel nanomaterials and their application in efficient removal of radionuclides. Sci. China Chem. 2019, 62, 933-967. [CrossRef]

22. Xie, Y.; Helvenston, E.M.; Shuller-Nickles, L.C.; Powell, B.A. Surface Complexation Modeling of Eu(III) and U(VI) Interactions with Graphene Oxide. Environ. Sci. Technol. 2016, 50, 1821-1827. [CrossRef] [PubMed]

23. Ghalami, Z.; Ghoulipour, V.; Khanchi, A. Highly efficient capturing and adsorption of cesium and strontium ions from aqueous solution by porous organic cage: A combined experimental and theoretical study. Appl. Surf. Sci. 2019, 471, 726-732. [CrossRef]

24. Ogata, F.; Nagai, N.; Ueta, E.; Nakamura, T.; Kawasaki, N. Biomass potential of virgin and calcined tapioca (cassava starch) for the removal of $\operatorname{Sr}(\mathrm{II})$ and Cs(I) from aqueous solutions. Chem. Pharm. Bull. 2018, 66, 295-302. [CrossRef] [PubMed]

25. Bisla, V.; Rattan, G.; Singhal, S.; Kaushik, A. Green and novel adsorbent from rice straw extracted cellulose for efficient adsorption of $\mathrm{Hg}$ (II) ions in an aqueous medium. Int. J. Biol. Macromol. 2020, 161, 194-203. [CrossRef]

26. Shi, X.; Qiao, Y.; An, X.; Tian, Y.; Zhou, H. High-capacity adsorption of Cr(VI) by lignin-based composite: Characterization, performance and mechanism. Int. J. Biol. Macromol. 2020, 159, 839-849. [CrossRef] [PubMed]

27. Barillet, S.; Adam-Guillermin, C.; Palluel, O.; Porcher, J.M.; Devaux, A. Uranium bioaccumulation and biological disorders induced in zebrafish (Danio rerio) after a depleted uranium waterborne exposure. Environ. Pollut. 2011, 159, 495-502. [CrossRef]

28. Cai, Y.; Yuan, F.; Wang, X.; Sun, Z.; Chen, Y.; Liu, Z.; Wang, X.; Yang, S.; Wang, S. Synthesis of core-shell structured $\mathrm{Fe}_{3} \mathrm{O}_{4} @$ carboxymethyl cellulose magnetic composite for highly efficient removal of Eu(III). Cellulose 2017, 24, 175-190. [CrossRef]

29. Chen, B.; Zhao, H.; Chen, S.; Long, F.; Huang, B.; Yang, B.; Pan, X. A magnetically recyclable chitosan composite adsorbent functionalized with EDTA for simultaneous capture of anionic dye and heavy metals in complex wastewater. Chem. Eng. J. 2019, 356, 69-80. [CrossRef]

30. Chen, H.; Shao, D.; Li, J.; Wang, X. The uptake of radionuclides from aqueous solution by poly(amidoxime) modified reduced graphene oxide. Chem. Eng. J. 2014, 254, 623-634. [CrossRef]

31. Chen, Z.; Xue, Z.; Chen, L.; Geng, Z.; Yang, R.; Chen, L.; Wang, Z. One-pot template-free synthesis of water-dispersive $\mathrm{Fe}_{3} \mathrm{O}_{4} @ \mathrm{C}$ nanoparticles for adsorption of bovine serum albumin. New J. Chem. 2013, 37, 3731-3736. [CrossRef]

32. Carvalho, T.; Pereira, A.d.S.; Bonomo, R.C.F.; Franco, M.; Finotelli, P.V.; Amaral, P.F.F. Simple physical adsorption technique to immobilize Yarrowia lipolytica lipase purified by different methods on magnetic nanoparticles: Adsorption isotherms and thermodynamic approach. Int. J. Biol. Macromol. 2020, 160, 889-902. [CrossRef] [PubMed]

33. Dos Santos, J.M.N.; Pereira, C.R.; Foletto, E.L.; Dotto, G.L. Alternative synthesis for $\mathrm{ZnFe}_{2} \mathrm{O}_{4} / \mathrm{chitosan}$ magnetic particles to remove diclofenac from water by adsorption. Int. J. Biol. Macromol. 2019, 131, 301-308. [CrossRef] [PubMed]

34. Hu, D.; Lian, Z.; Xian, H.; Jiang, R.; Wang, N.; Weng, Y.; Peng, X.; Wang, S.; Ouyang, X.K. Adsorption of Pb(II) from aqueous solution by polyacrylic acid grafted magnetic chitosan nanocomposite. Int. J. Biol. Macromol. 2020, 154, 1537-1547. [CrossRef]

35. Tanhaei, B.; Ayati, A.; Iakovleva, E.; Sillanpää, M. Efficient carbon interlayed magnetic chitosan adsorbent for anionic dye removal: Synthesis, characterization and adsorption study. Int. J. Biol. Macromol. 2020, 164, 3621-3631. [CrossRef]

36. Yu, S.; Cui, J.; Wang, J.; Zhong, C.; Wang, X.; Wang, N. Facile fabrication of Cu(II) coordinated chitosan-based magnetic material for effective adsorption of reactive brilliant red from aqueous solution. Int. J. Biol. Macromol. 2020, 149, 562-571. [CrossRef]

37. Zhang, M.; Zhang, Z.; Peng, Y.; Feng, L.; Li, X.; Zhao, C.; Sarfaraz, K. Novel cationic polymer modified magnetic chitosan beads for efficient adsorption of heavy metals and dyes over a wide $\mathrm{pH}$ range. Int. J. Biol. Macromol. 2020, 156, 289-301. [CrossRef]

38. Gabal, M.A.; Kosa, S.; Almutairi, T.S. Cr-substitution effect on the structural and magnetic properties of nano-sized $\mathrm{NiFe}_{2} \mathrm{O}_{4}$ prepared via novel chitosan route. J. Magn. Magn. Mater. 2014, 356, 37-41. [CrossRef] 
39. Li, Z.; Liu, Y.; Zou, S.; Lu, C.; Bai, H.; Mu, H.; Duan, J. Removal and adsorption mechanism of tetracycline and cefotaxime contaminants in water by $\mathrm{NiFe}_{2} \mathrm{O}_{4}$-COF-chitosan-terephthalaldehyde nanocomposites film. Chem. Eng. J. 2020, 382, 123008. [CrossRef]

40. Nishat, N.; Ahmad, S.; Tansir Ahamad, R. Synthesis and characterization of antibacterial polychelates of urea-formaldehyde resin with $\mathrm{Cr}(\mathrm{III}), \mathrm{Mn}(\mathrm{II}), \mathrm{Fe}(\mathrm{III}), \mathrm{Co}(\mathrm{II}), \mathrm{Ni}(\mathrm{II}), \mathrm{Cu}(\mathrm{II})$, and $\mathrm{Zn}(\mathrm{II})$ metal ions. J. Appl. Polym. Sci. 2006, 100, 928-936. [CrossRef]

41. Jiang, R.; Zhu, H.-Y.; Fu, Y.-Q.; Zong, E.-M.; Jiang, S.-T.; Li, J.-B.; Zhu, J.-Q.; Zhu, Y.-Y. Magnetic $\mathrm{NiFe}_{2} \mathrm{O}_{4} / \mathrm{MWCNTs}$ functionalized cellulose bioadsorbent with enhanced adsorption property and rapid separation. Carbohydr. Polym. 2020, 252, 117158. [CrossRef] [PubMed]

42. Liu, F.; Zhang, W.; Chen, W.; Wang, J.; Yang, Q.; Zhu, W.; Wang, J. One-pot synthesis of $\mathrm{NiFe}_{2} \mathrm{O}_{4}$ integrated with EDTA-derived carbon dots for enhanced removal of tetracycline. Chem. Eng. J. 2017, 310, 187-196. [CrossRef]

43. Deng, Y.; Zou, X.; Liu, Z.; Wang, J.; Wang, Z.; Tang, J. Co7Fe $3 / \mathrm{CoFe}_{2} \mathrm{O}_{4} @ \mathrm{C}$ Lamellar composites derived from Co-Fe LDH/PVA as an effective heterogeneous activator of peroxymonosulfate. J. Alloys Compd. 2021, 854, 157244. [CrossRef]

44. Gan, L.; Zhong, Q.; Geng, A.; Wang, L.; Song, C.; Han, S.; Cui, J.; Xu, L. Cellulose derived carbon nanofiber: A promising biochar support to enhance the catalytic performance of $\mathrm{CoFe}_{2} \mathrm{O}_{4}$ in activating peroxymonosulfate for recycled dimethyl phthalate degradation. Sci. Total Environ. 2019, 694, 133705. [CrossRef] [PubMed]

45. Ahamad, T.; Nishat, N. New antimicrobial epoxy-resin-bearing Schiff-base metal complexes. J. Appl. Polym. Sci. 2008, 107, 2280-2288. [CrossRef]

46. Alshehri, S.M.; Aldalbahi, A.; Al-Hajji, A.B.; Chaudhary, A.A.; in het Panhuis, M.; Alhokbany, N.; Ahamad, T. Development of carboxymethyl cellulose-based hydrogel and nanosilver composite as antimicrobial agents for UTI pathogens. Carbohydr. Polym. 2016, 138, 229-236. [CrossRef]

47. Nishat, N.; Hasnain, S.; Ahmad, T.; Parveen, A. Synthesis, characterization, and biological evaluation of new polyester containing Schiff base metal complexes. J. Therm. Anal. Calorim. 2011, 105, 969-979. [CrossRef]

48. Ikram, S.; Jacob, J.; Mahmood, K.; Mehboob, K.; Maheen, M.; Ali, A.; Amin, N.; Hussain, S.; Ashraf, F.; Ilyas, S.Z. A Kinetic study of Tb3+ and Dy3+ co-substituted $\mathrm{CoFe}_{2} \mathrm{O}_{4}$ spinel ferrites using temperature dependent XRD, XPS and SQUID measurements. Ceram. Int. 2020, 46, 15943-15948. [CrossRef]

49. Kulkarni, P.; Balkrishna, R.G.; Ghosh, D.; Rawat, R.S.; Medwal, R.; Chowdari, B.V.R.; Karim, Z.; Reddy, M.V. Molten salt synthesis of $\mathrm{CoFe}_{2} \mathrm{O}_{4}$ and its energy storage properties. Mater. Chem. Phys. 2021, 257, 123747. [CrossRef]

50. Li, S.; Wu, Y.; Zheng, Y.; Jing, T.; Tian, J.; Zheng, H.; Wang, N.; Nan, J.; Ma, J. Free-radical and surface electron transfer dominated bisphenol A degradation in system of ozone and peroxydisulfate co-activated by $\mathrm{CoFe}_{2} \mathrm{O}_{4}$-biochar. Appl. Surf. Sci. 2020, 147887, in press.

51. Li, X.; Sun, Y.; Zong, Y.; Wei, Y.; Liu, X.; Li, X.; Peng, Y.; Zheng, X. Size-effect induced cation redistribution on the magnetic properties of well-dispersed $\mathrm{CoFe}_{2} \mathrm{O}_{4}$ nanocrystals. J. Alloys Compd. 2020, 841, 155710. [CrossRef]

52. Tang, J.; Wang, K.; Lu, Y.; Liang, N.; Qin, X.; Tian, G.; Zhang, D.; Feng, S.; Yue, H. Mesoporous core-shell structure $\mathrm{NiFe}_{2} \mathrm{O}_{4} @$ polypyrrole micro-rod with efficient electromagnetic wave absorption in $\mathrm{C}, \mathrm{X}, \mathrm{Ku}$ wavebands. J. Magn. Magn. Mater. 2020, 514, 167268. [CrossRef]

53. Devi, R.; Gogoi, S.; Dutta, H.S.; Bordoloi, M.; Sanghi, S.K.; Khan, R. Au/ $\mathrm{NiFe}_{2} \mathrm{O}_{4}$ nanoparticle-decorated graphene oxide nanosheets for electrochemical immunosensing of amyloid beta peptide. Nanoscale Adv. 2020, 2, 239-248. [CrossRef]

54. Mansour, S.F.; Imam, N.G.; Goda, S.; Abdo, M.A. Constructive coupling between $\mathrm{BiFeO}_{3}$ and $\mathrm{CoFe}_{2} \mathrm{O}_{4}$; promising magnetic and dielectric properties. J. Mater. Res. Technol. 2020, 9, 1434-1446. [CrossRef]

55. Praveena, M.G.; Kumar, A.S.; Kala, M.S.; Bhowmik, R.N.; Nair, S.S.; Thomas, S.; Anantharaman, M.R. Interface assisted strain-induced magnetoelectric coupling in core-shell nanostructures of $\mathrm{CoFe}_{2} \mathrm{O}_{4} @ \mathrm{ZnO}$. J. Magn. Magn. Mater. 2020, 513, 167252. [CrossRef]

56. Qasim, M.; Asghar, K.; Das, D. Preparation and characterization of $\mathrm{CoFe}_{2} \mathrm{O}_{4}$ and $\mathrm{CoFe}_{2} \mathrm{O}_{4} @$ Albumen nanoparticles for biomedical applications. Ceram. Int. 2019, 45, 24971-24981. [CrossRef] 
57. Mahdikhah, V.; Ataie, A.; Babaei, A.; Sheibani, S.; Ow-Yang, C.W.; Abkenar, S.K. $\mathrm{CoFe}_{2} \mathrm{O}_{4} / \mathrm{Fe}$ magnetic nanocomposite: Exchange coupling behavior and microwave absorbing property. Ceram. Int. 2020, 46, 17903-17916. [CrossRef]

58. Ahamad, T.; Naushad, M.; Al-Maswari, B.M.; Ahmed, J.; Alothman, Z.A.; Alshehri, S.M.; Alqadami, A.A. Synthesis of a recyclable mesoporous nanocomposite for efficient removal of toxic $\mathrm{Hg} 2+$ from aqueous medium. J. Ind. Eng. Chem. 2017, 53, 268-275. [CrossRef]

59. Ahamad, T.; Naushad, M.; Alshehri, S.M. Fabrication of magnetic polymeric resin for the removal of toxic metals from aqueous medium: Kinetics and adsorption mechanisms. J. Water Process Eng. 2020, 36, 101284. [CrossRef]

60. Alqadami, A.A.; Naushad, M.; Alothman, Z.A.; Ahamad, T. Adsorptive performance of MOF nanocomposite for methylene blue and malachite green dyes: Kinetics, isotherm and mechanism. J. Environ. Manag. 2018, 223, 29-36. [CrossRef]

61. Naushad, M.; Ahamad, T.; AlOthman, Z.A.; Al-Muhtaseb, A.a.H. Green and eco-friendly nanocomposite for the removal of toxic $\mathrm{Hg}(\mathrm{II})$ metal ion from aqueous environment: Adsorption kinetics \& isotherm modelling. J. Mol. Liq. 2019, 279, 1-8.

62. Naushad, M.; Ahamad, T.; Sharma, G.; Al-Muhtaseb, A.a.H.; Albadarin, A.B.; Alam, M.M.; Alothman, Z.A.; Alshehri, S.M.; Ghfar, A.A. Synthesis and characterization of a new starch/SnO $\mathrm{S}_{2}$ nanocomposite for efficient adsorption of toxic Hg2+ metal ion. Chem. Eng. J. 2016, 300, 306-316. [CrossRef]

63. Ahamad, T.; Ruksana; Naushad, M.; Al-Maswari, B.M.; Alshehri, S.M. Fabrication of highly porous adsorbent derived from bio-based polymer metal complex for the remediation of water pollutants. J. Clean. Prod. 2019, 208, 1317-1326. [CrossRef]

64. Alqadami, A.A.; Naushad, M.; Abdalla, M.A.; Ahamad, T.; Abdullah Alothman, Z.; Alshehri, S.M.; Ghfar, A.A. Efficient removal of toxic metal ions from wastewater using a recyclable nanocomposite: A study of adsorption parameters and interaction mechanism. J. Clean. Prod. 2017, 156, 426-436. [CrossRef]

65. Goyal, N.; Gao, P.; Wang, Z.; Cheng, S.; Ok, Y.S.; Li, G.; Liu, L. Nanostructured chitosan/molecular sieve-4A an emergent material for the synergistic adsorption of radioactive major pollutants cesium and strontium. J. Hazard. Mater. 2020, 392, 122494. [CrossRef]

66. Hu, Y.; Guo, X.; Wang, J. Biosorption of Sr2+ and Cs+ onto Undaria pinnatifida: Isothermal titration calorimetry and molecular dynamics simulation. J. Mol. Liq. 2020, 319, 114146. [CrossRef]

67. Asgari, E.; Sheikhmohammadi, A.; Yeganeh, J. Application of the $\mathrm{Fe}_{3} \mathrm{O}_{4}$-chitosan nano-adsorbent for the adsorption of metronidazole from wastewater: Optimization, kinetic, thermodynamic and equilibrium studies. Int. J. Biol. Macromol. 2020, 164, 694-706. [CrossRef]

68. Mohammadabadi, S.I.; Javanbakht, V. Lignin extraction from barley straw using ultrasound-assisted treatment method for a lignin-based biocomposite preparation with remarkable adsorption capacity for heavy metal. Int. J. Biol. Macromol. 2020, 164, 1133-1148. [CrossRef]

Publisher's Note: MDPI stays neutral with regard to jurisdictional claims in published maps and institutional affiliations.

(C) 2020 by the authors. Licensee MDPI, Basel, Switzerland. This article is an open access article distributed under the terms and conditions of the Creative Commons Attribution (CC BY) license (http://creativecommons.org/licenses/by/4.0/). 